\title{
GLACIOLOGICAL AND OGEANOGRAPHIC CALCULATIONS OF THE MASS BALANCE AND OXYGEN ISOTOPE RATIO OF A MELTING ICE SHELF
}

\author{
By J. R. Potter, J. G. Paren, and J. Loynes*
}

(British Antarctic Survey, Natural Environment Research Council, High Cross, Madingley Road, Cambridge CB3 0ET, England)

\begin{abstract}
Glaciological estimates of the ice supply to George VI Ice Shelf are obtained by integrating the accumulation over the catchment. The basal melt (or possible shelf thickening) rates for the ice shelf are calculated by balancing the accumulation with calving and melting. We calculate an average equilibrium melt rate for the ice shelf of $2 \mathrm{~m} \mathrm{a}^{-1}$. If the ice shelf is in mass balance it alone provides $53 \mathrm{~km}^{3} \mathrm{a}^{-1}$ melt from its base compared to a total for Antarctica of only $320 \mathrm{~km}^{3} \mathrm{a}^{-1}$.

The mean oxygen isotope composition of recent accumulation on the catchment is determined by using accumulation and isotope data, supplemented by temperature measurements and a close empirical relationship between isotope ratio and temperature. The catchment has a mean isotope ratio of $-20.8 \%$ relative to SMOW.

Oceanographic work has previously shown that the sea-water under the ice shelf at the north of George VI Sound is Warm Deep Water modified by melting ice. The melting ice has an isotope ratio of $-20.3 \%$. The good agreement in isotope ratios suggest that the melting ice is from the catchment and because the basal ice of George VI Ice Shelf represents accumulation over the last few millennia the implication is that there has been no systematic change in the isotope composition of the accumulation during this period. This implies no secular change in either the elevation or the climatic temperature of this part of the ice sheet.
\end{abstract}

RÉsumé. Calculs glaciologiques et océanographiques du bilan de masse el du pourcentage de l'isotope de l'oxygène pour un shelf fondant. Des estimations glaciologiques de l'alimentation en glace pour le George VI Ice Shelf sont obtenues en sommant l'accumulation sur le bassin. La fonte basale du shelf (ou son amincissement possible) est calculée en faisant le bilan de l'accumulation, du vélage et de la fonte. On obtient un taux de fonte moyen d'équilibre pour le shelf de $2 \mathrm{~m} \mathrm{a}^{-1}$. Si le shelf de glace est équilibré en bilan, rien que cela conduit à une fonte basale de $53 \mathrm{~km}^{3} \mathrm{a}^{-1}$ à comparer aux $320 \mathrm{~km}^{3} \mathrm{a}^{-1}$ seulement de l'ensemble de l'Antarctique.

La teneur moyenne en isotope d'oxygène des accumulations récentes sur le bassin est déterminée par les données d'accumulation et d'isotope jointes à des relevés de température et une très bonne relation empirique température - taux d'isotope. Le taux moyen d'isotope du bassin, relatif au pérature - taux d'isotope.
SMOW, est de $-20,8 \%$.

Des travaux océanographiques ont antérieurement montré que l'eau de mer sous le shelf au nord de la George VI Sound est de l'eau chaude

\section{INTRODUCTION}

The Antarctic ice sheet is the major determinant of global sea-level and any departure from a state of mass balance is therefore of great interest. The net mass input to an ice sheet can, in principle, be calculated by integrating net ice accumulation over area. If an ice sheet is in balance this mass accretion must equal that flowing onto the sea and melting, either directly from an ice-shelf base or by calving and subsequent iceberg melting. An oceanographic calculation is needed to determine whether such melting is less than or exceeds that required to balance the accumulation. For an ice shelf and that part of the ice sheet which forms its catchment, any positive difference between the mass accumulation and the mass depletion rate must result in a thickening or extension of either the ice sheet or its associated ice shelf. Thus both a glaciological estimate of ice accumulation and an oceanographic estimate of ice depletion are required to determine the state of balance.

The ice that accumulates within a catchment is formed from water molecules comprising the various profonde modifiée par la fusion de la glace. L'eau de fusion a une teneur en isotope de $-20,3 \%$. La bonne concordance des teneurs en isotope suggère que la glace qui fond provient du bassin et du fait que la glace basale du shelf représente l'accumulation sur les quelques derniers millénaires, cela a pour conséquence qu'il n'y a pas eu de changement systématique dans la teneur en isotope de l'accumulation pendant cette période. Cela implique aucun changement séculaire, que ce soit dans l'altitude ou bien dans la température climatique de cette partie de la calotte de glace.

Zusammenfassung. Glaziologische und ozeanographische Berechnungen der Massenbilanz und des Sauerstoffisotopenverhältnisses eines schmelzenden Schelfeises. Glaziologische Abschätzungen des Eisnachschubs zum George VI Ice Shelf werden durch Integration der Akkumulation über das Einzugsgebie gewonnen. Die Schmelz- oder möglicherweise Zuwachsraten an der Unterseite des Schelfeises werden aus der Bilanz zwischen Akkumulation bzw. Kalben und Schmelzen berechnet. Es ergibt sich eine mittlere Gleichgewichtsschmelzrate von $2 \mathrm{~m}$ pro Jahr für das Schelfeis. Wenn das Schelfeis sich im Massengleichgewicht befindet, liefert es allein $53 \mathrm{~km}^{3} \mathrm{Schmelz}$ wasser pro Jahr von seiner Unterseite, verglichen mit nur $320 \mathrm{~km}^{3}$ pro Jahr für ganz Antarktika.

Die mittlere Zusammensetzung an Sauerstoffisotopen der jüngeren Akkumulation im Einzugsgebiet wird bestimmt aus Akkumulations- und Isotopendaten, ergänzt durch Temperaturmessungen und eine empirische Beziehung zwischen dem Isotopenverhältnis und der Temperatur. Das Einzugsgebiet hat ein mittleres Isotopenverhältnis von $-20,8 \%$ relativ zu SMOW.

Ozeanographische Arbeiten haben früher gezeigt, dass das Meerwasser unter dem Schelfeis im Norden des George VI Sound warmes Tiefenwasser, verändert durch schmelzendes Eis, ist. Das schmelzende Eis hat ein Isotopen-verhältnis von $-20,3 \%$. Die gute Úbereinstimmung der Isotopenverhältnisse lassen vermuten, dass das schmelzende Eis aus dem Einzugsgebiet stammt. Da das Eis an der Unterseite des George VI Ice Shel die $\Lambda$ kkumulation über einige der letzten Jahrtausende darstellt, ergibt sich die unerwartete Folgerung, dass in dieser Zeitspanne keine systematische Anderung in der Isotopenzusammensetzung der Akkumulation eingetreten ist. Dies würde bedeuten, dass weder die Höhe noch die klimatische Temperatur dieses Teiles des Eisschildes sich langfristig geändert hat.

stable and radioactive isotopes of hydrogen and oxygen. The stable isotopes cannot be created or destroyed as the snow is compacted and recrystallizes into glacier ice. In a catchment which terminates in an ice shelf there must be a close association between the isotope composition of the snow in the catchment and that being removed by melting and iceberg calving. It is possible to deduce the isotope ratio of $180 / 160$ in fresh water discharging into the sea by examining profiles of salinity and isotope composition in the sea-water. With both glaciological and oceanographic observations we are able to investigate the transfer of mass and the 180 isotope through a catchment from deposition at the surface to melting from the bottom of an ice shelf. We are thus able to discuss the secular changes that may have occurred in a period comparable to the residence time of ice in the catchment.

\section{THE CATCHMENT}

George VI Sound is a narrow channel running northsouth between the west coast of the Antarctic Peninsula and Alexander Island, widening and curving to the west at its southern extremity (Fig. 1). George VI Ice Shelf occupies this channel and is derived from 


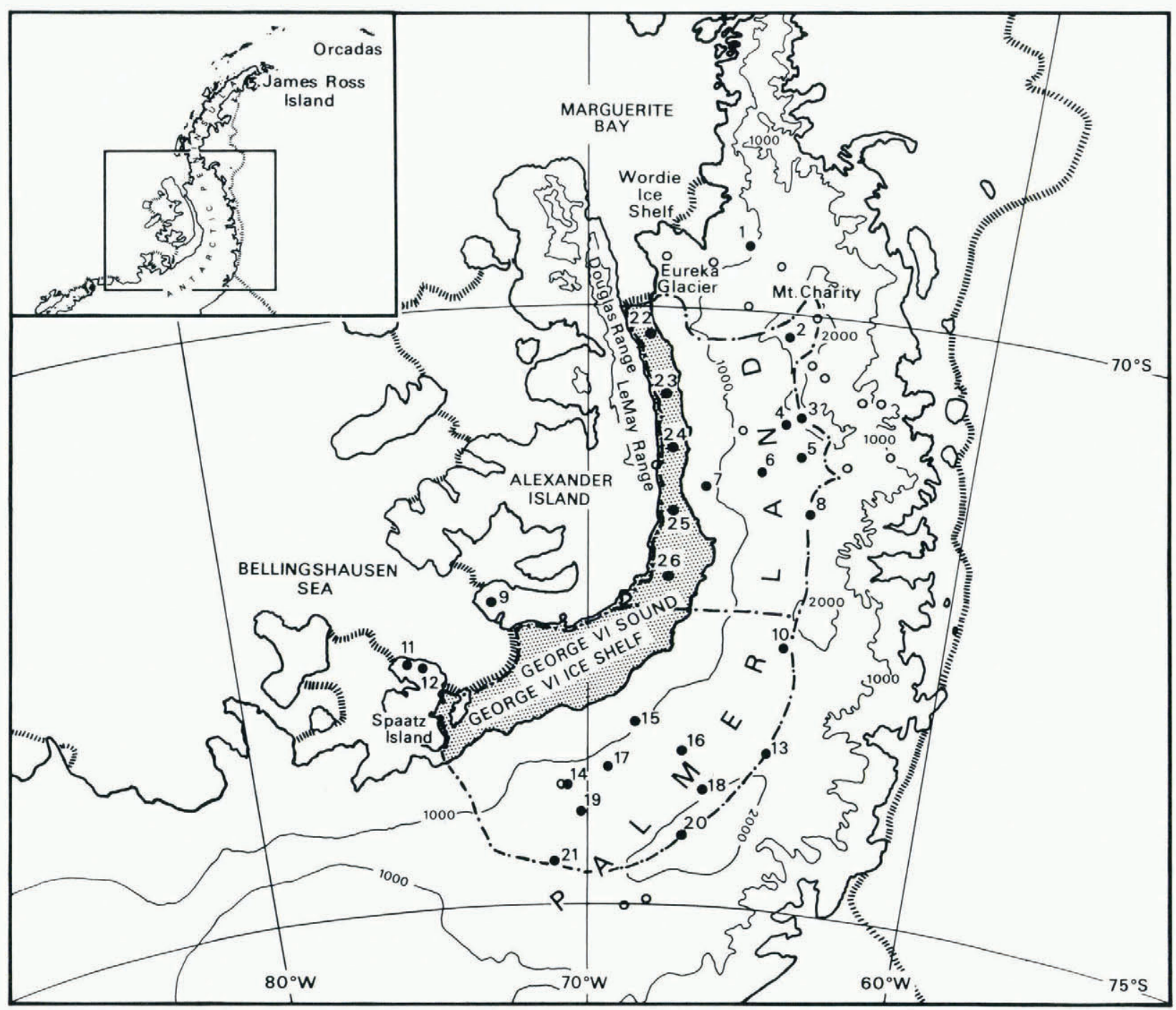

Fig. 1. George VI Ice Shelf (shaded) and its catchment (outlined by a dot-dashed line). Accumulation data sites are shown by solid circles numbered as in the Appendix. Hollow circles represent sites of temperature only. Elevation contous are shown at $1000 \mathrm{~m}$ intervals.

accumulation over the Pacific sector of the Antarctic Pehinsula, the ice shelf, and parts of Alexander Island. The major source of ice is the Antarctic Peninsula, whose ice streams almost reach the western margin of the ice shelf. In contrast, the Alexander Island ice extends only a few kilometres into the ice shelf.

To determine the mass and isotope balance of the catchment we need to know à and $\delta_{a}$ for the whole of the catchment, where $\dot{a}$ is the accumulation rate as a function of position and $\delta_{a}$ is the corresponding isotope ratio. The accumulation data are sparse south of lat. $72^{\circ} 30^{\prime} \mathrm{S}$., particularly over the ice shelf, and in addition the calving rate for the southern ice front is uncertain. The north of the catchment, on the other hand, has a more variable accumulation pattern and our accumulation model may be less representative in this area. For these reasons we have divided the ice shelf and its catchment into northern and southern sections which are evaluated separately.

The northern part of Alexander Island is mountainous and its accumulation is difficult to assess. We know that the part of the island facing George VI Ice Shelf is in a severe precipitation shadow (Bishop and Walton, 1981). The low accumulation rate and small area, perhaps $8 \%$ of the northern catchment, makes the ice contribution from northern Alexander Island small. The southern part of Alexander Island is lowerlying and probably has a more typical accumulation rate. Even so, the island only represents some $4 \%$ of the southern catchment area. For simplicity we have therefore chosen to neglect Alexander Island and to bear in mind that our final ice budget results may be some $3-4 \%$ low as a result.

The two catchment sections are therefore contained within the boundaries of the east coast of Alexander Island, the peninsula crest and assumed flow-lines at the northern and southern extremities. The catchment boundaries are shown in Figure 1 and were evaluated from three sources:

(1) A NOAA-2 satellite very-high-resolution radiometer image of the Antarctic Peninsula, taken on 22 October 1973 in the visible band on orbit 4657 . This was used to locate the ice divide at the ridge of the peninsula.

(2) Topographic maps published by the Directorate of Overseas Surveys for the British Antarctic Survey (BAS).

(3) Antarctica sketch map 1:500 000. Palmer Land (north part). Reston, Virginia, U.S. Geological Survey, 1979. 


\section{THE GLACIOLOGICAL EVIDENCE}

\section{Accumulation data}

The Appendix gives the available accumulation data and Figure 1 shows their distribution within the catchment. These data originate from three sources:

\section{(1) Sites 1-14}

0xygen isotope ratios measured from ice cores exceeding $10 \mathrm{~m}$ length supported by beta radioactivity and density measurements provided accumulation rates for these sites. Typically the derived accumulation rates are averages over the period 1965-75.

\section{(2) Sites 15-21}

Data from the Antarctic Peninsula Traverse (196162) provide evidence of the accumulation rate in the southern part of the catchment and adjacent area. Behrendt $(1963,1965)$ correlated seismic refraction travel times with accumulation rates estimated by Shimizu (1964) from studies in pits $2 \mathrm{~m}$ to $3 \mathrm{~m}$ deep and with accumulation rates at Eights station (1at. $75^{\circ} 15^{\prime}$ S., long. $77^{\circ} 07^{\prime} \mathrm{W}$.) determined by oxygen isotope measurements. Behrendt's analysis showed that 6 out of 16 of Shimizu's estimates were incompatible with either the seismic or isotope evidence. For the remaining 10 pits, Shimizu's accumulation rates had an error of $0.04 \mathrm{~m} \mathrm{a}^{-1}$ in the linear correlation of seismic velocity and accumulation in a self-consistent data set which included the isotope-derived accumulation for Eights station. Behrendt's study predated Kohnen's (1971) more powerful application of seismic data to determine accumulation rates, but it is still a valid analysis for an area of varying accumulation but with similar ambient temperatures. Behrendt's accumulation estimates are long-period averages typically taken over $40 \mathrm{~m}$ of ice depth and along a $200 \mathrm{~m}$ line. Such accumulation rates should be more representative than those obtained from the wall of a shallow pit. Behrendt estimated the uncertainty in his accumulation values to be $0.03 \mathrm{~m} \mathrm{a}^{-1}$. Typically his accumulation values are averages over the period 1900-60.

(3) Sites 22-26 on George VI Ice Shelf.

Several hundred aluminium stakes were set up on George VI Ice Shelf in networks of varying size and shape between latitudes $70^{\circ} \mathrm{S}$. and $72^{\circ} 30^{\prime} \mathrm{S}$. Accumulation rates were measured at these stakes over several years between 1969 and 1976 (Bishop and Walton, 1981). Between latitudes $70^{\circ} 30^{\prime} \mathrm{S}$. and $72^{\circ} \mathrm{S}$. extensive melting occurs at the surface in summer and al though most of this melt refreezes in situ, some is lost to the sea through moulins in the ice shelf. Reynolds (1981 $[b])$ estimates the water drainage loss to be $0.4 \pm$ $0.2 \mathrm{~km}^{3} \mathrm{a}^{-1}$ and we have added this to the accumulation measurements integrated over the melt area to determine the local mass input. The accumulation data were then averaged over 30 min latitude bands over the ice shelf north of 1 at. $72^{\circ} 30^{\prime} \mathrm{S}$.

A smooth function of latitude, longitude, elevation, and their second-order combinations was fitted to the accumulation data in the Appendix using a multiple regression to minimize the r.m.s. deviation between the function and data. Based on the known topography of the catchment, a contour plot of the accumulation function values for the catchment is shown in Figure $2 \mathrm{a}$. The accumulation map reflects the track of maritime depressions moving in from the Bellingshausen Sea or on a southerly course from South America which increase precipitation near the west and north coasts respectively. That part of the

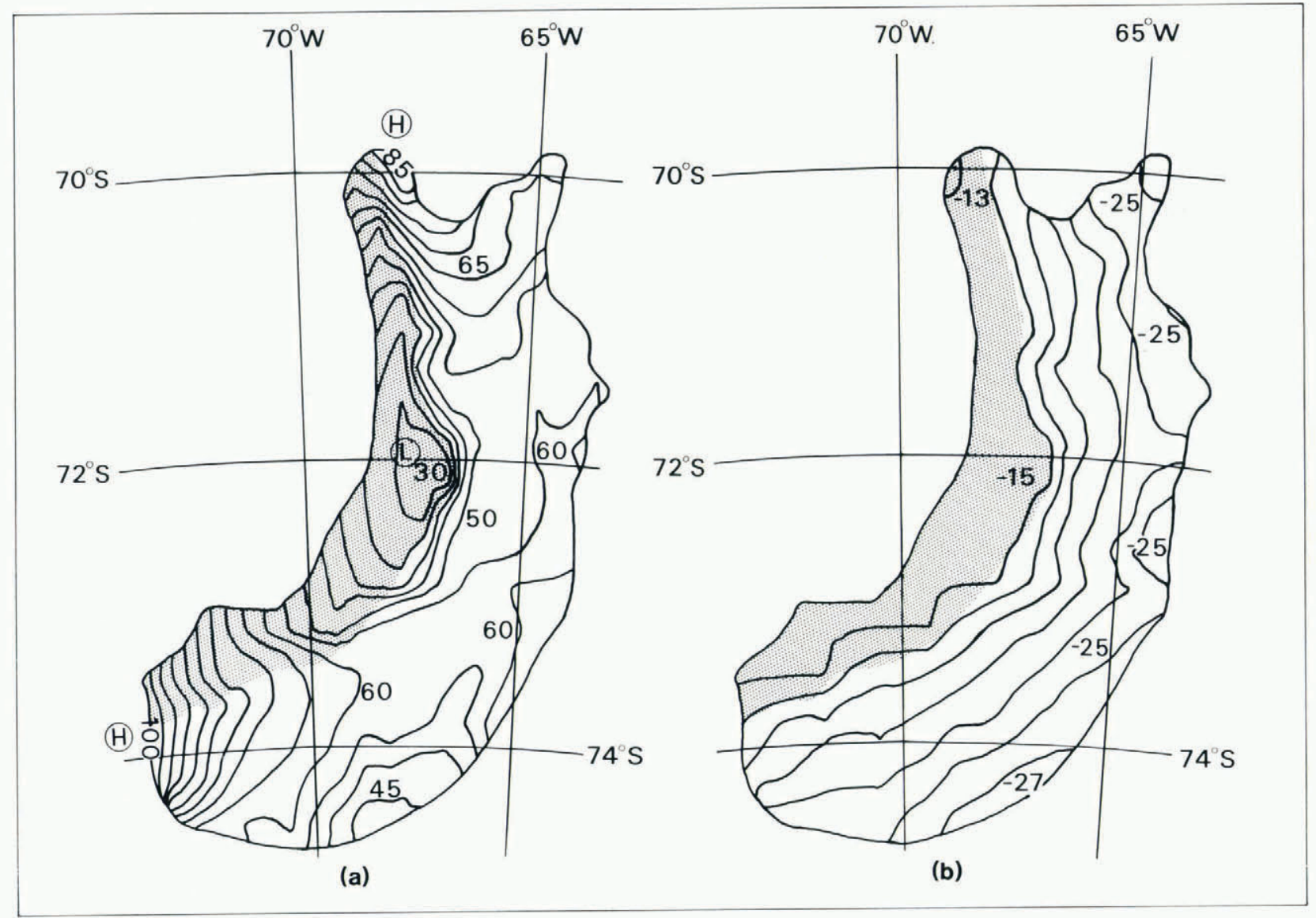

Fig. 2. The catchment with (a) contorss of the modelled accumulation in cm $a^{-1}$ of ice and (b) contows of the derived $\delta$ field in $\%$ oo with respect to SMOW. The ice shelf is shown shaded. 
catchment with elevation over $1500 \mathrm{~m}$ has an almost uniform accumulation rate of $0.56 \mathrm{~m} \mathrm{a}^{-1}$ ice, the standard deviation of points over $1500 \mathrm{~m}$ high being only $0.07 \mathrm{~m} \mathrm{a}^{-1}$. There is a marked accumulation shadow in the lee of the Douglas and LeMay ranges (up to $2987 \mathrm{~m} \mathrm{high}$ ) on Alexander Island which reduces accumulation on part of the ice shelf to less than half that found elsewhere in the catchment.

\section{Oxygen isotope data}

0xygen isotope measurements from $10 \mathrm{~m}$ ice cores are available from only 14 sites within the catchment. A more complete set of values was obtained by using the close relationship between temperature and the isotope ratio of precipitation, studied by Peel and Clausen (1982).

\section{TEMPERATURE $\left({ }^{\circ} \mathrm{C}\right)$}

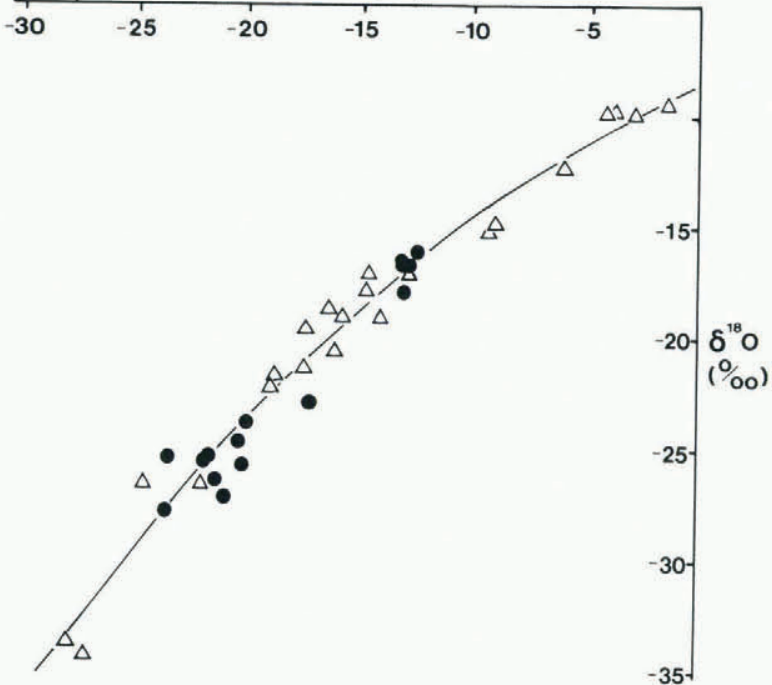

Fig. 3. The T- $\delta$ relationship both for sites in the catchment, shown by solid circles, and other sites in the Antarctic Peninsula, shown by triangles.

Figure 3 shows the relationship between temperature and isotope ratio for all the sites within or near the catchment for which both quantities are known. The values are tabulated in the Appendix. The relationship between temperature and isotope ratio used for the calculations in this paper and in the curve in Figure 3 is

$$
\delta=(1795.05-3.0568 \mathrm{~T}-264540 / \mathrm{T}) 0 / 00
$$

where $T$ is the absolute temperature and $\delta$ is with respect to SMOW. The scatter of the data about this empirical smooth curve is in part due to the interannual variability in the climate. Temperature data are generally from the bottom of a $10 \mathrm{~m}$ drill hole and will closely approximate the mean temperature of the previous one or two years. The isotope data are generally an average over $5-10$ years, but this is not long enough to prevent part years in the ice core biasing the result towards that particular season. Nevertheless, the correlation between temperature and isotope ratio is good, and given the temperature of a site, this enables us to assign an isotope ratio with only a small expected error $( \pm 1.20 / 00)$.

The temperate field of the catchment was determined by the multiple regression of temperatures against latitude and elevation from 53 sites in the Antarctic Peninsula. Martin and Peel (1978) and Reynolds (1981[a]) have previously derived the temperature field of the Antarctic Peninsula, showing that latitude and elevation are the important controlling parameters. For our regression we took the temperature data of Reynolds (1981[a]) and added the previously unconsidered data from Shimizu (1964) together with several more recent measurements. All the temperature data used are listed with their origin in the Appendix. Our resulting equation for temperature as a function of latitude and elevation is as follows:

$$
\begin{aligned}
T=(265.35 & \left.-0.73 \text { (latitude }-70^{\circ} \mathrm{S} .\right)- \\
& -6.38 \times \text { elevation }) \mathrm{K}
\end{aligned}
$$

where the elevation is in kilometres. This equation agrees very closely with the results of Martin and Peel (1978) and Reynolds (1981[a]) and has a standard deviation of $1.0 \mathrm{deg}$. The standard deviation is of the same size as inter-annual temperature variations over the period of the temperature measurements (Limbert, $1974,1980)$. Although the annual temperature variation will be heavily damped at $10 \mathrm{~m}$ (the typical measurement depth) the inter-annual and, even more noticeably, any progressive trend over periods greater than about 5 years will cause a scatter of the temperature data points. We therefore conclude that the specified temperature field has close to the minimum error that climatic variability allows. The isotope field derived from this temperature field is shown as a contour map over the catchment in Figure $2 b$.

\section{Integration over the catchment}

To evaluate the total accumulation and its isotope composition we must integrate the relevant values over the catchment. Since the catchment is irregular in shape this is difficult analytically but simple to do numerically by summing over a finite-element grid network which contains the catchment. The grid used consisted of elements of 15 min latitude by 30 min longitude from lat. $69^{\circ} \mathrm{S}$. to $73^{\circ} \mathrm{S}$. and somewhat larger elements of $20 \mathrm{~min}$ latitude by $40 \mathrm{~min}$ longitude from lat. $73^{\circ} \mathrm{S}$. to $75^{\circ} \mathrm{S}$. The larger elements in the southern part of the grid network reflect the poorer accumulation data for that area. The catchment limits were defined by assigning a weighting of ' 1 ' to each element wholly in the catchment, a ' 0 ' to each element wholly excluded from the catchment and some representative fraction for each element partially occupied by the catchment. The catchment including the ice shelf occupied 211 elements in all. Between lat. $69^{\circ} \mathrm{S}$ and $73^{\circ} \mathrm{S}$, elevations were assessed from unpubli shed base maps at a scale of 1:250 000 prepared for the BAS $1: 500000$ geological map series. South of 1 at. $73^{\circ} \mathrm{S}$ elevations were assessed from British Antarctic Territory $1: 3000000$ (BAS Misc.2 edition 1) 1981. The accumulation and isotope ratio was calculated for each element from the latitude, longitude, and elevation. The elements were multiplied by their weighting factor and the area they represent (a function of latitude). The total accumulation and isotope compasition were then evaluated by summation. The results are shown in Table I.

\section{THE OCEANOGRAPHIC EVIDENCE}

The oceanographic data obtained at the northern ice front are displayed in Figure 4. Between the depths of $10 \mathrm{~m}$ and $700 \mathrm{~m}$, temperature T and oxygen isotope composition $\delta$ are linearly correlated with salinity S. Linear T-S relationships provide evidence of the mixing of two water masses. Lennon and others (1982) have shown that the gradient of the T-S diagram is in good agreement with a theoretical model of glacier ice melting in sea-water. A thermohaline convective layer occupies the water column from the base of the ice shelf at approximately $75 \mathrm{~m}$ below sealevel to at least $200 \mathrm{~m}$. Between $75 \mathrm{~m}$ and $200 \mathrm{~m}$ depth the T-S relationship is linear with a gradient of $2.39 \pm 0.05 \mathrm{deg} 0 / 00^{-1}$ whereas the gradient of the theoretical model is $2.49 \mathrm{deg} 0 / 00^{-1}$. Lennon and others (1982) suggest that Warm Deep Water moves slowly under the ice shelf at depth, upwells supplying heat to melt the ice shelf, and then flows away northwards with the ice melt water in a surface jet current concentrated at the west side of the ice shelf by Coriolis force. 
TABLE I. ACCUMULATION OVER PALMER LAND AND THE ICE SHELF, ICE LOSSES THROUGH SURFACE DRAINAGE, CALVING, AND CALCULATED EQUILIBRIUM BASAL MELT RATES FOR THE NORTHERN, SOUTHERN, AND ENTIRE ICE SHELF

$\begin{array}{cccccc}\begin{array}{c}\text { Ice flux } \\ \text { into ice } \\ \text { shelf }\end{array} & \begin{array}{c}\text { Ice-shelf } \\ \text { accumula- } \\ \text { tion }\end{array} & \begin{array}{c}\text { Flux into ice } \\ \text { shelf }+ \text { ice-shelf } \\ \text { accumulation }\end{array} & \begin{array}{c}\text { Melt-water } \\ \text { drainage }\end{array} & \begin{array}{c}\text { Iceberg } \\ \text { calving }\end{array} & \begin{array}{c}\text { Equilibrium } \\ \text { basal melt }\end{array} \\ -20.8 \pm 0.5 & -13.9 \pm 1.0 & -19.6 \pm 0.5 & -14.0 \pm 1.0 & -14.0 \pm 1.0 & -19.8 \pm 0.5\end{array}$
$\delta(\%)$
$-20.8 \pm 0.5$

$18.4 \pm 2.1$

$3.7 \pm 1.2$

$22.1 \pm 2.4$

$0.4 \pm 0.2$

$0.3 \pm 0.1$

$21.3 \pm 2.4$

$\left(\begin{array}{lll}k m^{3} & a^{-1} & \text { ice })\end{array}\right.$

$(17.4)$ *

$\left(2.07 \pm 0.23 \mathrm{~m} \mathrm{a}^{-1}\right)$

Area

$\left(10^{3} \mathrm{~km}^{2}\right)$

$31.7 \pm 0.8$

$10.3 \pm 0.1$

$42.0 \pm 0.8$

$10.3 \pm 0.1$

$\bar{\delta}(0 / 00)$

$-22.5 \pm 0.4$

$-15.0 \pm 0.9$

$-20.7 \pm 0.4$

$-15.0 \pm 1.0$

$-21.5 \pm 0.5$

$\begin{array}{ll}\left(\mathrm{km}^{3} \mathrm{a}^{-1} \text { ice }\right) & 27.1 \pm 1.8 \\ & (22.5)^{*}\end{array}$

$8.4 \pm 1.0 \quad 35.5 \pm 2.0$

$4.0 \pm 0.6$

$31.6 \pm 2.1$

thern

chment

$27.1 \pm 1.8$
$(22.5) *$

$2.5 \pm$

$\left(2.17 \pm 0.14 \mathrm{~m} \mathrm{a}^{-1}\right)$

Area

$\left(10^{3} \mathrm{~km}^{2}\right)$

$45.6 \pm 1.2$

$14.6 \pm 0.1$

$60.1 \pm 1.2$

$14.6 \pm 0.1$

$\begin{array}{lccc}\bar{\delta}(0 / 00) & -21.8 \pm 0.3 & -14.7 \pm 0.7 & -20.3 \pm 0.3 \\ \left(\mathrm{~km}^{3} \mathrm{a}^{-1} \text { ice }\right) & \begin{array}{c}45.6 \pm 2.7 \\ (39.9)^{\star}\end{array} & 12.1 \pm 1.6 & 57.6 \pm 3.1 \\ \begin{array}{c}\text { Area } \\ \left(10^{3} \mathrm{~km}^{2}\right)\end{array} & 77.2 \pm 1.5 & 24.9 \pm 0.2 & 102.1 \pm 1.5\end{array}$

$-14.0 \pm 1.0$

$-14.9 \pm 1.0$

$-20.8 \pm 0.3$

th anc
th of

th of

$\left(10^{3} \mathrm{~km}^{2}\right)$

$77.2 \pm 1.5$

$.1 \pm 1.5$

$24.9 \pm 0.2$

M. Reynolds, unpublished data

Although the jet current has been observed, and the quantity of ice melt it carries away has been calculated, it is not known how much of the ice shelf is affected by this circulation and therefore what area supplies the ice melt. This prevents a firm oceanographic calculation of basal melt rate.

The oxygen isotope-salinity $(\delta-S)$ diagram allows us to deduce the oxygen isotope composition of the ice melting in the sea and that of the Warm Deep Water, the water type at the warm saline end of the mixing line. Both oxygen isotope ratio and salinity are overall conservative properties in the mixing of two water types. The processes which alter the isotope composition of sea-water are mixing, precipitation, evaporation, and, in polar regions, melting or freezing of ice. It is an unhappy coincidence that the slopes of $\delta-S$ lines determined by evaporation and precipitation can be very similar to those determined by ice melting and freezing (Craig and Gordon, 1965). For this reason we must identify the dominant mechanisms before making interpretations of isotope data.

First, and most importantly, thermodynamic arguments presented above based on T-S profiles taken at the northern ice front show that the water properties under the ice are determined solely by ice melting in Warm Deep Water. This eliminates bottom freezing, seaice formation, liquid precipitation, evaporation, and continental run-off as significant elements because these processes would produce quite different T-S gradients. We are left only with ice-shelf melt and snow precipitation over the sea in Marguerite Bay. Lennon and others (1982) have found that there is no net southward flow from Marguerite Bay towards the ice shelf in the zone of mixing. We therefore expect the local influence of melt water from the base of the ice shelf to be predominant.

If water of salinity $S$ is formed as a result of the mixing of glacier ice of isotope composition $\delta$ with Warm Deep Water of salinity SWDW and isotope composition $\delta$ WDW, then the isotope composition of the mixture, $\delta$, is given approximately by

$$
\delta=\delta_{I}+\left(S / S_{W D W}\right)\left(\delta_{W D W}-\delta_{I}\right) .
$$

This expression is not exact due to a non-linearity introduced by the definition of salinity, leading to an error in deduced values of $\delta$ I of some $3.5 \%$ (Craig and Gordon, 1965; Paren and Potter, 1984). There are $44 \delta-5$ data pairs plotted in Figure $4(b)$, taken from profiles at three sites. Measurements taken from surface sea-water and at $1 \mathrm{~m}$ depth have been omitted since they are dominated by local surface effects and are unsuitable for investigating the large-scale net melting of the ice shelf. A linear regression of the 44 values gives $\delta_{I}=-20.3 \%$ 

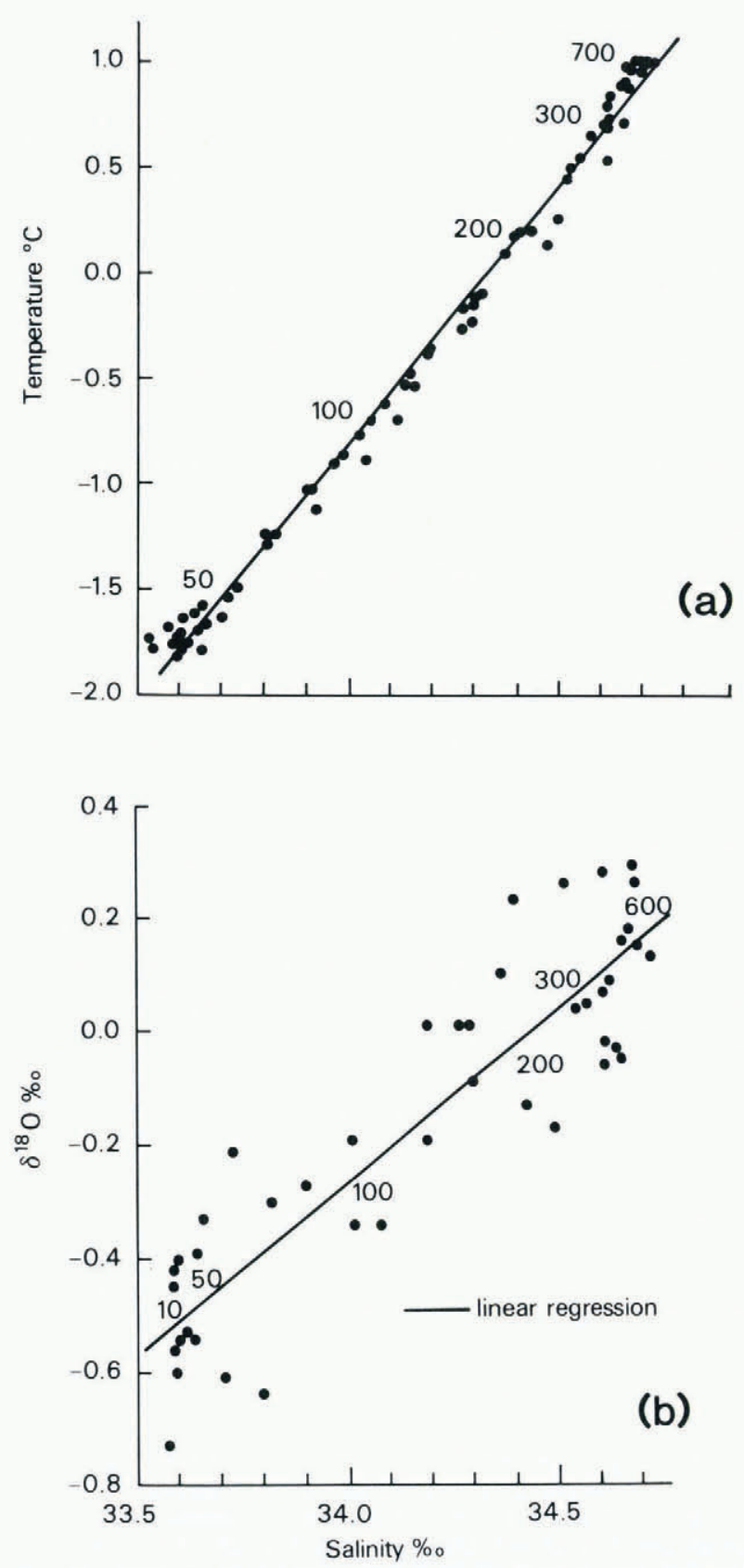

Fig. 4. T-S and $\delta-S$ relationships in the sea at the northern ice front of George VI Ice Shelf. Measurement depths in metres below sea-level are shown beside some data points.

with a standard deviation of $1.5 \%$ (after correcting for the $3.5 \%$ error). The Warm Deep Water of salinity $34.72 \%$ has a $\delta_{\text {WDW }}$ value of $+0.16 \pm 0.04 \%$.

\section{EQUILIBRIUM MASS BALANCE}

In general, conservation of mass determines that

$$
\int \dot{\mathrm{a}} \mathrm{dx}=\dot{\mathrm{A}}=\mathrm{dM} / \mathrm{dt}+2 \dot{\mathrm{M}}_{\mathrm{i}}
$$

where $\dot{a}$ is the accumulation rate, $\dot{A}$ is the total accumulation rate, $\dot{M}$ is the total mass in the catchment, $M_{j}$ are the mass loss rates and the integration is performed over the catchment area $x$. We shall begin by assuming $d M / d t=0$, the equilibrium condition, and evaluate the various $\dot{M}_{i}$.
Run-off to the sea

Net ablation occurs at the low-lying margins of the peninsula, at the surface and at the bottom of the ice shelf. Although basal melt predominates as the source of ablation (Reynolds, 1981[b]) we must allow for the estimated $0.4 \mathrm{~km}^{3} \mathrm{a}^{-1}$ of water which percolates directly into the sea from the melt lakes between lat. $70^{\circ} 30^{\prime} \mathrm{S}$. and $72^{\circ} \mathrm{S}$.

\section{Calving at the northern ice front}

Multi-year sea ice in the entrance of George VI Sound allows the ice front to calve only episodically, the ice front advancing for several years before breaking back. Between 1974 and 1979 some $25 \mathrm{~km}^{3}$ of ice shelf was lost in this way, probably during the austral summer of 1976-77. The long time interval and irregularity of these surges makes it unreasonable to assess the rate of calving from changes in ice front position especially since accurate observations have only been possible since the launching of the LANDSAT 1 satellite in 1972 . Since the northern ice front seems to be retreating, which is a non-equilibrium state, we chose to perform our mass equilibrium calculations using forward ice velocities at the ice fronts integrated with ice-front height and width to give an ice flux. Also, we use as a boundary for balance calculations a notional boundary which, at present, coincides with the ice front. In this way any non-equilibrium calving behaviour of the ice fronts causing advance or retreat does not affect the validity of our equilibrium calculation. To do this we must calculate the forward ice velocities near both ice fronts. For the north, Bishop and Walton (1981) gave surface ice velocities for a stake scheme some $40 \mathrm{~km}$ south of the ice front. The stake scheme velocity was resolved parallel to the sound and following Paterson (1981, p. 174) the velocity increase with distance down a flow line was calculated for an ice shelf with parallel-sided flow. This gave an icefront velocity of $125 \mathrm{~m} \mathrm{a}^{-1}$ with a corresponding equilibrium ice loss of $0.3 \mathrm{~km}^{3} \mathrm{a}^{-1}$.

calving at the southern ice front

The southern ice front is much less well known and we can make only a crude estimate of ice velocity. Integrating the mass accumulation over the southern section of the catchment and dividing by the length of the grounding line and its mean ice thickness gives an ice velocity of $230 \mathrm{~m} \mathrm{a}^{-1}$ at the grounding line. Kotlyakov and others (1978) suggest that the average ice-front velocity for small Antarctic ice shelves is $200 \mathrm{~m} \mathrm{a}^{-1}$ and for all Antarctic ice shelves some $500 \mathrm{~m} \mathrm{a}^{-1}$. Ice velocity is unlikely to decrease along a flow line once the ice is afloat and so we have taken $300-400 \mathrm{~m} \mathrm{a}^{-1}$ as the likely range of the southern ice-front velocity. This results in a speculative estimate of $3.5-4.6 \mathrm{~km}^{3} \mathrm{a}^{-1}$ ice for the equilibrium calving loss.

Melting from the bottom surface of the ice shelf We are now in a position to calculate the only remaining mass loss, basal melting. Details of the calculation are given in Table I. For the northern part of the ice shelf the equilibrium basal melt rate is $2.07 \pm 0.23 \mathrm{~m} \mathrm{a}^{-1}$ and in the south the value is $2.17 \pm 0.14 \mathrm{~m} \mathrm{a}^{-1}$.

If $\mathrm{dM} / \mathrm{dt} \neq 0$ then the ice shelf and catchment are not in equilibrium and the predicted basal melt rates should be re-interpreted as the sum of basal melting and some change in thickness of either the ice shelf or catchment ice sheet. Reynolds (unpublished) calculated an approximate value for the ice flux across the grounding line into George VI Sound. The calculation was done by combining ice depths from radio echosounding with velocities partly from measured stake schemes and partly from assumed velocity profiles across 42 glacier units nourishing the ice shelf. Reynolds' unpublished data show that north of lat. $72^{\circ} 30^{\prime} \mathrm{S}$. the grounding line flux is based on field 
data and has a value of $17.4 \mathrm{~km}^{3} \mathrm{a}^{-1}$ ice. Further south, there are no field measurements of velocity and only a crude estimate of flux is possible. Based on the accumulation map of Figure $2 a$, we estimate the ice flux across the grounding line north of lat. $72^{\circ} 30^{\prime} \mathrm{S}$. to be $18.4 \mathrm{~km}^{3} \mathrm{a}^{-1}$, some $6 \%$ larger than Reynolds' estimate. This discrepancy is small compared to the uncertainties in each calculation. One interpretation of this result is that the present-day accumulation balances the contemporary ice flow into the sound, confining any non-equilibrium behaviour to the ice shelf. The equilibrium basal melt rates can, in this case, be considered as the arithmetic sum of basal melt and ice-shelf thickening. If also the ice shelf is in equilibrium then we predict a total melt rate from its base of $53 \mathrm{~km}^{3} \mathrm{a}^{-1}$. Kotlyakov and others (1978) estimated the total ice-shelf bottom melting for Antarctica at only $320 \mathrm{~km}^{3} \mathrm{a}^{-1}$. If it is in equilibrium, George VI Ice Shelf would appear to be a major contributor to the ice-melt budget of Antarctica, supplying a sixth of the total ice shelf melt despite its small size.

\section{EQUILIBRIUM ISOTOPE BALANCE}

Conservation of mass and isotope species determines that

$$
j \delta_{a} \dot{a} d x=\delta_{t} d M / d t+2 \delta_{i} \dot{M}_{j}
$$

where $\delta_{a}$ is the oxygen isotope ratio of the accumulation $\dot{a}, \delta_{t}$ is the mean isotope ratio of the thickening or thinning ice, and the $\delta_{j}$ are average isotope values for the mass losses $\hat{M}_{i}$. Once aga in we shall begin by considering $\mathrm{dM} / \mathrm{dt}=0$. We define $\bar{\delta}$ by

$$
\bar{j}=j \delta_{a} \dot{a} d x / \int \dot{a} d x=\int \delta_{a} \dot{a} d x / \dot{A}
$$

so that $\delta$ represents the accumulation-weighted mean isotope ratio. Considering ice losses to be primarily calving $\left(\delta_{c}, \dot{M}_{c}\right)$, melting $\left(\delta_{m}, \hat{M}_{m}\right)$, and surface drainage $\left(\delta_{d}, M_{d}\right)$, we see that

$$
\delta_{m}=\left(\delta A-\delta_{c} M_{c}-\delta_{d} M_{d}\right) /\left(A-M_{c}-M_{d}\right) \text {. }
$$

$\delta_{m}$ is, then, an equilibrium estimate of the isotope ratio of melting ice derived solely from glaciological evidence. By considering particle paths of the ice emerging at each ice front we find that the majority of such ice is derived from local precipitation and so $\delta_{c}$ has been evaluated accordingly. The value of $\delta$ will essentially be that of the accumulation in the surface melt zone.

One problem which could affect the accuracy of our calculated $o_{m}$ is that our values of $\delta_{a}$ are largely derived from a smooth function of position evaluated from the $\delta-T$ relationship of Figure 3 and a knowledge of mean annual temperature distribution throughout the catchment. Any region which experiences atypical evaporation causing fractionation will deviate from the model employed. One such area is known: between lat. $70^{\circ} 30^{\prime} \mathrm{S}$, and $72^{\circ} \mathrm{S}$. melt lakes develop on the ice shelf. These lakes are open for perhaps six weeks in the summer and cover some $30 \%$ of the ice shelf area between these latitudes. Assuming $30 \mathrm{~mm}$ of the water surface evaporates and that the evaporated water has an isotope ratio $12 \%$ below that of the melt lake, this biases the isotope ratio of the ice remaining in the northern part of the ice shelf by only $0.03 \%$, a negligible amount.

Table I displays the isotope ratios calculated for the ice shelf and Palmer Land separately for the northern and southern sections. From glaciological observations we deduce that the $\delta$ value of ice melting in the sea is $-19.8 \pm 0.5 \%$ in the north of the catchment and $-21.5 \pm 0.5 \%$ in the south. If we allow for the $0.4 \mathrm{~km}^{3} \mathrm{a}^{-1}$ of drainage water with a $\delta$ value of $-14 \%$, which will presumably mix with the ice melt from the northern part of the ice shelf, we reduce the isotope ratio that we expect to observe in the sea to $-19.7 \%$. Even then, the difference between the glaciological estimate of the ice-melt $\delta$ value and that deduced from the $\delta-S$ relationship in the sea at the northern ice front $(-20.3 \%)$ is still only $0.6 \%$. This is insignificant compared with the mutual standard deviation of $1.6 \%$ ootween the two estimates. We therefore conclude that the ice melting at the northern ice front is virtually all from the ice shelf without a significant contribution from sea ice or snow precipitated over, the sea which would have $\delta$ values of approximately $+2 \%$ and $-13 \%$ respectively.

\section{SECULAR CHANGES IN THE ANTARCTIC PENINSULA}

Temperature

Limbert (1980) has shown that the Antarctic Peninsula is currently undergoing a climatic warming of up to $0.8 \mathrm{deg} /$ decade and suggests that this warming is part of a cycle, several of which have occurred in the last century, rather than a secular change. Limbert (personal communication) has compiled the temperature record from Orcadas (lat. $60^{\circ} 45^{\prime} \mathrm{S}$., long. $44^{\circ} 43^{\prime} \mathrm{W}$.) for the years 1904-78 which shows these cycles. The record shows that the post-1965 period, which heavily influences our temperature measurements, is no more than $0.7 \mathrm{deg}$ warmer than the average for the first half of the century. The $\delta$ field which we have used is strongly temperature dependent and is applicable to contemporary accumulation; the Orcadas record allays the fear that it is not representative of this century. Analysis of a deuterium record from an ice core spanning the years 1781-1981 from James Ross Island in the Antarctic Peninsula shows no persistent temperature trend for this 200 year period (Dr L. Merlivat, presentation at IAMAP symposium at IUGG Hamburg, 1983). The $\delta$ value deduced from the $\delta-S$ relationship in the sea is relevant to accumulation from the present time to a few thousand years ago now melting from the under-side of the ice shelf. We might expect any secular warming to produce a discrepancy between the two $\delta$ values. If we assume that the oceanic circulation conveys water through the entire length of George VI Sound, we should compare the oceanographically derived $\delta$ value for old ice with the average $\delta$ value for the catchment. Such a comparison indicates that the old ice is $0.5 \%$ "warmer" than the catchment ice; an insignificant difference compared to the mutual standard deviation between the two estimates. If, alternatively, we assume that the ice modifying the sea-water at the northern ice front comes from the north of the catchment, then we should use the $\delta$ value for that area for comparison with the $\delta$ value from the sea. In this case we find that the old ice is $0.6 \%$ "colder", also an insignificant difference. Furthermore, from our estimate of the mutual standard deviation for the $\delta$ values we can be $80 \%$ confident that the old ice melting from the base of the ice shelf was deposited in a climate on average'no more than $2 \%$ "colder" than present.

\section{Accumulation}

Doake (1982) discusses a level line set out in 1975 on the plateau of the Antarctic Peninsula at lat. $70^{\circ} 35^{\prime} \mathrm{S}$., long. $64^{\circ} 16^{\prime} \mathrm{W}$. adjacent to the catchment of George VI Ice Shelf. The line was relevelled five years later in 1980 by C.W.M. Swithinbank (personal communication). The observations showed no change in the surface level line over the five-year period within the accuracy of about $\pm 30 \mathrm{~mm}$. This implies that accumulation is currently balancing outward ice flow from the plateau crest. Reynolds' calculation for the ice flux across the grounding line of George VI Ice Shelf, for which it is difficult to assess an expected error, shows that the old ice flowing off Palmer Land near sea-level balances present accumulation within $6 \%$. These measurements imply 
that as far as we can tell the Palmer Land ice sheet is currently near balance.

George VI Ice Shelf, however, is unlikely to be in steady state. Bi shop and Walton (1981) calculated basal melt rates for the ice shelf from strain measurements assuming steady state. According to Doake (1982) their calculated melt pattern is physically unrealistic, suggesting that both thinning and thickening may occur in the ice shelf. But the ice shelf as a whole may be in equilibrium. Bishop and Walton (1981) predict a mean equilibrium melt rate of some $2 \mathrm{~m} \mathrm{a}^{-1}$, which is consistent with our result. If the mean basal melt rate is close to $2 \mathrm{~m} \mathrm{a}^{-1}$, sufficient to maintain overall equilibrium, George VI Ice Shelf is an important source of ice melt in the Antarctic mass balance. Alternatively, if the mean melt rate is less, there will be an overall thickening of the ice shelf. Oceanographic considerations (Lennon and others, 1982) suggest that the mean melt rate is at least $1 \mathrm{~m} \mathrm{a}^{-1}$ and is probably no greater than $2 \mathrm{~m} \mathrm{a}^{-1}$ making overall thinning an unlikely possibility and limiting any overall thickening to less than $1 \mathrm{~m} \mathrm{a}^{-1}$. Since the current rate of accumulation will support the present mass flux at the grounding line, we would expect any net thickening to continue for some time to come. The northern ice front, however, is at present retreating, presumably in a delayed response to an earlier trough in the ice supply. If the ice shelf is currently thickening, we should see the northern ice front advance again as this effect propagates along the shelf.

Pourchet and others (1983) show that accumulation rates over much of Antarctica including the Antarctic Peninsula have risen by up to $40 \%$ in the period 1965 80 compared to the period 1955-65. If this is so, either the present accumulation is high compared to a long-term average, or the earlier part of this century represented something of a drought. Whichever is the case, it appears that the ice flux across the grounding line, which corresponds with some average of accumulation over several thousand years, is similar to that accumulating at the present time.

We conclude that there are probably quite large variations in the temperature and accumulation rate with periods ranging from decades to several centur ies but that there is no strong evidence for a secular change in the Antarctic Peninsula over the last few millennia.

\section{CONCLUSIONS}

We have successfully modelled the extent, accumulation pattern, and isotope-ratio variations of the catchment for George VI Ice Shelf. Equilibrium estimates of the basal melt rates predict values of some $2 \mathrm{~m} \mathrm{a}^{-1}$ which are in agreement with the strain-rate derived estimates of Bishop and Walton (1981). There may be some non-equilibrium behaviour causing the ice shelf to thicken in places, but an average thickening rate can be no more than $1 \mathrm{~m} \mathrm{a}^{-1}$. The isotope ratio of the present-day accumulation on the catchment is, within the expected error, that of the ice melt which modifies the Warm Deep Water from Marguerite Bay. We have therefore shown that the water under the northern part of George VI Ice Shelf is produced locally rather than from advected surface water from Marguerite Bay. Finally, we have found no strong evidence for secular climatic change in the Antarctic Peninsula.

\section{ACKNOWLEDGEMENTS}

The authors are particularly indebted to Dr H.B. Clausen of the Geophysical Isotope Laboratory, University of Copenhagen, for undertaking the isotope measurements on the ice cores and sea-water samples. We would also like to thank Dr C.S.M. Doake for his help and advice on ice dynamics and radio-echo icedepth information and J.L. Wade for his able programming assistance.

APPENDIX. TEMPERATURE, ACCUMULATION, AND ISOTOPE DATA

Sites near and within George VI Ice Shelf catchment

\begin{tabular}{|c|c|c|c|c|c|c|c|}
\hline $\begin{array}{l}\text { Site } \\
\text { No. }\end{array}$ & Latitude & Longitude & $\underset{\mathrm{m}}{\text { Altitude }}$ & $\begin{array}{c}\text { Temperat ure } \\
{ }^{\circ} \mathrm{C}\end{array}$ & $\begin{array}{l}\text { Accumulation } \\
\mathrm{m} \mathrm{a}^{-1} \text { of ice }\end{array}$ & $\begin{array}{l}5180 \\
0 / 00\end{array}$ & Reference \\
\hline 1 & $69^{\circ} 30^{\prime} \mathrm{S}$. & $66^{\circ} 16^{\prime} W$. & 870 & -12.9 & 1.06 & -16.80 & 1 \\
\hline 2 & $70^{\circ} 14^{\prime} \mathrm{s}$. & $65^{\circ} 05^{\prime}$ W. & 2100 & -21.9 & 0.53 & -25.65 & 6 \\
\hline 3 & $70^{\circ} 50^{\prime} \mathrm{s}$. & $64^{\circ} 27^{\prime}$ W. & 1987 & -21.4 & 0.48 & -26.48 & 1 \\
\hline 4 & $70^{\circ} 53^{\prime} \mathrm{s}$. & $64^{\circ} 57^{\prime} \mathrm{W}$. & 1860 & -20.2 & 0.48 & -25.77 & 1 \\
\hline 5 & $71^{\circ} 15^{\prime} \mathrm{s}$. & $64^{\circ} 30^{\prime} \mathrm{W}$. & 2010 & -23.7 & 0.56 & -25.43 & 1 \\
\hline 6 & $71^{\circ} 23^{\prime} \mathrm{S}$. & $65^{\circ} 30^{\prime} \mathrm{W}$. & 1547 & -20.0 & 0.61 & -23.90 & 1 \\
\hline 7 & $71^{\circ} 29^{\prime} \mathrm{S}$. & $66^{\circ} 58^{\prime} W$. & 946 & -13.1 & 0.64 & -18.00 & 1 \\
\hline 8 & $71^{\circ} 42^{\prime} \mathrm{S}$. & $64^{\circ} 05^{\prime}$ ' W. & 1886 & -20.4 & 0.46 & -24.72 & 1 \\
\hline 9 & $72^{\circ} 30^{\prime} \mathrm{S}$. & $72^{\circ} 50^{\prime} \mathrm{W}$. & 488 & -13.3 & 0.95 & -16.55 & 1 \\
\hline 10 & $72^{\circ} 47^{\prime} \mathrm{S}$. & $64^{\circ} 30^{\prime} \mathrm{W}$. & 1797 & -21.8 & 0.57 & -25.40 & 1 \\
\hline 11 & $72^{\circ} 56^{\prime} \mathrm{s}$. & $75^{\circ} 15^{\prime} \mathrm{W}$. & 539 & -13.3 & 1.25 & -16.69 & 1 \\
\hline 12 & $72^{\circ} 59^{\prime} \mathrm{S}$. & $74^{\circ} 45^{\prime} \mathrm{W}$. & 408 & -12.5 & 1.29 & -16.12 & 8 \\
\hline 13 & $73^{\circ} 42^{\prime} \mathrm{S}$ & $64^{\circ} 47^{\prime}$ W. & 2007 & -23.8 & 0.47 & -27.84 & 1 \\
\hline 14 & $74^{\circ} 01^{\prime} \mathrm{S}$. & $70^{\circ} 38^{\prime} \mathrm{W}$. & 1140 & -17.3 & 0.97 & -22.97 & 8 \\
\hline 15 & $73^{\circ} 32^{\prime} \mathrm{s}$. & $68^{\circ} 37^{\prime} \mathrm{W}$. & 1045 & -16.0 & 0.42 & & 2 \\
\hline 16 & $73^{\circ} 43^{\prime} \mathrm{S}$. & $67^{\circ} 16^{\prime} W$. & 1575 & -20.0 & 0.52 & & 2 \\
\hline 17 & $73^{\circ} 54^{\prime} \mathrm{S}$. & $69^{\circ} 26^{\prime} W$. & 1215 & -18.0 & 0.41 & & 2 \\
\hline 18 & $74^{\circ} 04^{\prime} \mathrm{S}$. & $66^{\circ} 35^{\prime} \mathrm{W}$. & 2120 & -24.6 & 0.58 & & 2 \\
\hline 19 & $74^{\circ} 16^{\prime} \mathrm{S}$. & $70^{\circ} 10^{\prime} \mathrm{W}$. & 1434 & -20.0 & 0.42 & & 2 \\
\hline 20 & $74^{\circ} 27^{\prime} \mathrm{s}$. & $67^{\circ} 08^{\prime} W$. & 2150 & -25.4 & 0.42 & & 2 \\
\hline 21 & $74^{\circ} 38^{\prime} \mathrm{S}$. & $71^{\circ} 03^{\prime} \mathrm{W}$. & 1802 & -23.1 & 0.40 & & 2 \\
\hline 22 & $70^{\circ} 15^{\prime} \mathrm{s}$. & $68^{\circ} 27^{\prime} W$. & 15 & & 0.67 & & 3 \\
\hline 23 & $70^{\circ} 45^{\prime} \mathrm{s}$. & $68^{\circ} 00^{\prime} W$. & 20 & & 0.25 & & 3 \\
\hline 24 & $71^{\circ} 15^{\prime} \mathrm{s}$. & $67^{\circ} 56^{\prime} W$. & 25 & & 0.22 & & 3 \\
\hline 25 & $71^{\circ} 45^{\prime} \mathrm{s}$. & $67^{\circ} 41^{\prime} \mathrm{W}$. & 35 & & 0.23 & & 3 \\
\hline 26 & $72^{\circ} 15^{\prime} \mathrm{s}$. & $67^{\circ} 46^{\prime}$ W. & 45 & & 0.55 & & 3 \\
\hline
\end{tabular}


Data for other sites used to define the temperature field of the Antarctic Peninsula and the relationship between $\delta$ and temperature

\begin{tabular}{|c|c|c|c|c|c|}
\hline Latitude & Longitude & $\underset{\mathrm{m}}{\text { Altitude }}$ & $\begin{array}{c}\text { Temperat wose } \\
{ }^{\circ} \mathrm{C}\end{array}$ & $\begin{array}{l}\$ 180 \\
0 / 00\end{array}$ & Referenc \\
\hline $62^{\circ} 05^{\prime} \mathrm{s}$. & $58^{\circ} 24^{\prime} W$. & 19 & -2.4 & & 4 \\
\hline $62^{\circ} 12^{\prime} \mathrm{s}$. & $58^{\circ} 58^{\prime} w$. & 14 & -3.8 & -9.50 & 5 \\
\hline $62^{\circ} 59^{\prime} \mathrm{s}$. & $60^{\circ} 34^{\prime} \mathrm{W}$. & 8 & -2.6 & & 4 \\
\hline $63^{\circ} 24^{\prime} \mathrm{S}$. & $56^{\circ} 59^{\prime} W$. & 11 & -5.6 & & 4 \\
\hline $64^{\circ} 05^{\prime} \mathrm{s}$. & $59^{\circ} 35^{\prime} \mathrm{W}$. & 1806 & -14.8 & -17.13 & 1 \\
\hline $64^{\circ} 13^{\prime} \mathrm{S}$. & $57^{\circ} 38^{\prime} W$. & 1620 & -12.9 & & 4 \\
\hline $64^{\circ} 13^{\prime} \mathrm{s}$. & $57^{\circ} 38^{\prime} W$. & 1500 & -14.2 & & 4 \\
\hline $64^{\circ} 46^{\prime} \mathrm{S}$. & $64^{\circ} 05^{\prime}$ '. & 20 & -3.2 & & 4 \\
\hline $65^{\circ} 15^{\prime} \mathrm{s}$. & $64^{\circ} 16^{\prime} \mathrm{W}$. & 10 & -3.5 & & 4 \\
\hline $66^{\circ} 25^{\prime} \mathrm{s}$. & $64^{\circ} 57^{\prime}$ 'W. & 1937 & -15.9 & -19.08 & 1. \\
\hline $67^{\circ} 32^{\prime} \mathrm{S}$. & $66^{\circ} 00^{\prime} W$. & 1750 & -16.5 & -18.70 & 1 \\
\hline $67^{\circ} 34^{\prime} \mathrm{S}$. & $68^{\circ} 08^{\prime} W$. & 20 & -6.4 & & 4 \\
\hline $67^{\circ} 46^{\prime} S$. & $68^{\circ} 55^{\prime} \mathrm{W}$. & 14 & -4.7 & & 4 \\
\hline $68^{\circ} 07^{\prime} \mathrm{s}$. & $66^{\circ} 18^{\prime} \mathrm{W}$. & 1315 & -15.0 & & 7 \\
\hline $68^{\circ} 08^{\prime} \mathrm{S}$. & $65^{\circ} 54^{\prime} W$. & 1125 & -15.0 & & 7 \\
\hline $69^{\circ} 36^{\prime} \mathrm{S}$. & $68^{\circ} 09^{\prime} W$. & 660 & -11.4 & & 6 \\
\hline $69^{\circ} 40^{\prime} \mathrm{s}$. & $65^{\circ} 30^{\prime} \mathrm{W}$. & 1994 & -19.1 & & 7 \\
\hline $69^{\circ} 42^{\prime} \mathrm{S}$. & $67^{\circ} 08^{\prime}$ 'W. & 1020 & -13.1 & & 6 \\
\hline $69^{\circ} 58^{\prime} \mathrm{S}$. & $66^{\circ} 14^{\prime} W$. & 1630 & -16.9 & & 6 \\
\hline $70^{\circ} 00^{\prime} \mathrm{S}$ & $75^{\circ} 20^{\prime} \mathrm{W}$ & 595 & -12.1 & & 1 \\
\hline $70^{\circ} 01^{\prime} \mathrm{s}$. & $64^{\circ} 29^{\prime} \mathrm{W}$. & 2131 & -21.0 & -27.13 & 1 \\
\hline $70^{\circ} 25^{\prime} \mathrm{S}$. & $64^{\circ} 32^{\prime} W$ & 1861 & -20.7 & & 7 \\
\hline $70^{\circ} 29^{\prime} S$. & $64^{\circ} 12^{\prime} W$. & 1360 & -17.7 & & 6 \\
\hline $70^{\circ} 42^{\prime} \mathrm{s}$. & $62^{\circ} 45^{\prime} W$. & 1140 & -16.7 & & 6 \\
\hline $70^{\circ} 43^{\prime} \mathrm{s}$. & $63^{\circ} 09^{\prime} W$. & 1860 & -18.2 & & 7 \\
\hline $70^{\circ} 59^{\prime} \mathrm{S}$. & $66^{\circ} 15^{\prime} \mathrm{W}$. & 1101 & -14.8 & & 7 \\
\hline $71^{\circ} 07^{\prime} \mathrm{s}$. & $62^{\circ} 20^{\prime} \mathrm{W}$. & 1050 & -16.6 & -25.94 & 1 \\
\hline $71^{\circ} 14^{\prime} \mathrm{S}$. & $63^{\circ} 22^{\prime} \mathrm{W}$. & 1752 & -22.1 & -26.68 & 1 \\
\hline $71^{\circ} 20^{\prime} \mathrm{s}$. & $68^{\circ} 17^{\prime} \mathrm{W}$. & 65 & -11.1 & & 4 \\
\hline $73^{\circ} 29^{\prime} \mathrm{S}$. & $70^{\circ} 08^{\prime}$ W. & 600 & -13.3 & & 4 \\
\hline $74^{\circ} 00^{\prime} \mathrm{S}$. & $70^{\circ} 45^{\prime} \mathrm{W}$. & 1160 & -17.1 & & 4 \\
\hline $74^{\circ} 58^{\prime} S$. & $68^{\circ} 12^{\prime} \mathrm{W}$. & 1721 & -22.8 & & 3 \\
\hline
\end{tabular}

References: 1, Peel and Clausen (1982); 2, Behrendt (1963, 1965), Shimizu (1964);

3, Bishop and Walton (1981); 4, Reynolds (1981[a]); 5, Morgan (1982);

6, J.W. Mumford - personal communication; 7, Martin and Peel (1978).

\section{REFERENCES}

Behrendt, J.C. 1963. Seismic measurements on the ice sheet of the Antarctic Peninsula. Jormal of Geophysical Research, Vol. 68, No. 21, p. 5973-90.

Behrendt, J.C. 1965. Densification of snow on the ice sheet of Ellsworth Land and the southern Antarctic Peninsula. Joronal of Glaciology, Vol. 5, No. 40, p. 451-60.

Bishop, J.F., and Walton, J.L.W. 1981. Bottom melting under George VI Ice Shelf, Antarctica. Jownal of Glaciology, Vol. 27, No. 97, p. 429-47.

Craig, H., and Gordon, L.I. 1965. Deuterium and oxygen18 variations in the ocean and the marine atmosphere. (In Tongiorgi, E., ed. Stable isotopes in oceanographic studies and paleotemperatures. Proceedings of the third spoleto Conference in spoleto, Italy. Pisa, V. Lischi e Figli, p. 9-130.)

Doake, C.S.M. 1982. State of balance of the ice sheet in the Antarctic Peninsula. Annals of Glaciology, Vol. 3, p. 77-82.

Kohnen, H. 1971. The relation between seismic firn structure, temperature, and accumulation. Zeitschrift fï Gletscherkinde and Glazialgeologie, Bd. 7, Ht. 1-2, p. 141-51.

Kotlyakov, V.M., and others. 1978. The ice budget of Antarctica, by V.M. Kotlyakov, K.S. Losev, and I.A. Loseva. Polar Geography, Vol. 2, No. 4, p. 251 62 .
Lennon, P.W., and others. 1982 . Oceanographic observations from George VI Ice Shelf, Antarctic Peninsula, by P.W. Lennon, J. Loynes, J.G. Paren, and J.R. Potter. Annals of Glaciology, Vol. 3, P. 178-83.

Limbert, D.W.S. 1974. Variations in the mean annual temperature for the Antarctic Peninsula, 1904-72. Polar Record, Vol. 17, No. 108, p. 303-06.

Limbert, D.W.S. 1980. [Surface temperature changes in Antarctica, including the Antarctic Peninsula from 1944 to 1978.] British Antarctic Survey Annual Report, 1979-80, p. 25-28.

Martin, P.J., and Peel, D.A. 1978. The spatial distribution of $10 \mathrm{~m}$ temperatures in the Antarctic Peninsula. Joronal of Glaciology, Vol. 20, No. 83, p. 31117 .

Morgan, V.I. 1982. Antarctic ice sheet surface oxygen isotope values. Journal of Glaciology, Vol. 28, No. 99, p. 315-23.

Paren, J.G., and Potter, J.R. 1984. Isotopic tracers in polar seas and glacier ice. Jowmal of Geophysical Research, Vol. 89, No. Cl, p. 749-50.

Paterson, W.S.B. 1981. The physics of glaciers. Second edition. 0xford, etc., Pergamon Press. (Pergamon International Library.)

Peel, D.A., and Clausen, H.B. 1982. Oxygen-isotope and total beta-radioactivity measurements on $10 \mathrm{~m}$ ice cores from the Antarctic Peninsula. Jovenal of Glaciology, Vol. 28, No. 98, p. 43-55. 
Pourchet, M., and others. 1983. Some meteorological applications of radioactive fallout measurements in Antarctic snows, by M. Pourchet, F. Pinglot, and C. Lorius. Jounal of Geophysical Research, Vol. 88, No. C10, p. 6013-20.

Reynolds, J.M. 1981[a]. The distribution of mean annual temperatures in the Antarctic Peninsula. British Antarctic Survey. Bulletin, No. 54, p. 123-33.

Reynolds, J.M. 1981[b]. Lakes on George VI Ice Shelf, Antarctica. Polar Record, Vol. 20, No. 128, p. 425-32.
Reynolds, J.M. Unpublished. Geophysical studies of the ice of the Antarctic Peninsula. [Ph.D. thesis, Council for National Academic Awards, London, Engl and, 1983.]

Shimizu, H. 1964. Glaciological studies in West Antarctica, 1960-1962. (In Mellor, M. ed. Antarctic snow and ice studies. Washington, D.C., American Geophysical Union, p. 37-64. (Antarctic Research Series, Vol.2.))

MS. received 9 November 1983 